\title{
Writing the Experiences and (Corporeal) Knowledges of Women of Color into Educational Studies: A Colloquium
}

\author{
A. B. V. M. M. Armstrong-Carela-Martínez-Pérez-Ruiz Guerrero \\ New Mexico State University
}

Follow this and additional works at: https://newprairiepress.org/piper

Part of the African American Studies Commons, Bilingual, Multilingual, and Multicultural Education Commons, Chicana/o Studies Commons, Women's History Commons, and the Women's Studies Commons

\section{Recommended Citation}

Armstrong-Carela-Martínez-Pérez-Ruiz Guerrero, A. (2017). Writing the Experiences and (Corporeal) Knowledges of Women of Color into Educational Studies: A Colloquium. Pedagogy \& (Im)Possibilities across Education Research (PIPER), 1 (1). https://doi.org/10.4148/2576-5795.1002 


\title{
Writing the Experiences and (Corporeal) Knowledges of Women of Color into Educational Studies: A Colloquium
}

\author{
Abstract \\ In this colloquium, we share collaborative ideas that came about during a weekend retreat. We center our \\ discussions on Chicana and Black feminisms and Womanism, specifically addressing how women of \\ color feminisms inspire us; imagining/defining space; tensions within our sisterhoods; transforming \\ (inner)coloniality by embracing our lived herstories; and how Chicana and Black feminisms and \\ Womanism transform educational studies. We leave readers with hopes for our-selves, our fields, our \\ sisters, and for the world. While not exact tellings of our pláticas during our retreat, we capture and share \\ the essence of burning questions, ideas, and hopes that arose for us when thinking and talking about \\ women of color feminisms and educational studies.

\section{Concepts, Ideas, People} \\ Sisterhood/s, Space, Coloniality, Educational Studies, Collective Action, Empowerment, Healing \\ Epistemologies, Methods, and Theories \\ Women of Color Feminisms, Corporeal/Lived Experiences as, Theories in the Flesh, Black Feminisms, \\ Chicana Feminism, Womanism

\section{Cover Page Footnote} \\ Our surnames are listed in alphabetical order and are intentionally left unseparated to demonstrate \\ collective authorship. For Correspondence with Author(s): Amanda Armstrong at aarmstr0@nmsu.edu, \\ Berta Carela at bcarela1@nmsu.edu, Vanessa Lina Martínez at vlm473@nmsu.edu, Michelle Salazar \\ Pérez at michelle.s.perez@gmail.com, or Margarita Ruiz Guerrero ogamlm@hotmail.com.
}




\section{Introduction: Conceptualizing our Colloquium}

We are honored to be part of this inaugural issue of PiPER. For our colloquium, we share collaborative ideas that came about during a weekend retreat two hours away from our university in southern New Mexico. We express our ideas as women of color, not with individual academic distinctions of student, professor, or university program directors and staff - rather as a sisterhood that exudes love, laughter, and sharing of struggles, resistance and empowerment. We center our musings and hopes on our connections to women of color feminisms, specifically Chicana and Black feminisms, and Womanism. The five of us, as African Americans, Chicanas, and Latinas from the United States, Mexico and the Dominican Republic, share our desires to write ourselves into history (Pérez, 1999). The white and historically male, heteronormative spaces of higher education, technology, and early childhood education (our respective fields) moves us to challenge systemic oppressions through theorizing our everyday lived experiences (Anzaldúa, 1987; Collins, 2008; hooks, 2000b; Lorde, 1984; Maparyan, 2012)—not just as individual actions for healing, but for collective empowerment. In doing so, we transform educational studies by centering the knowledges of our elders, recognizing our interconnections, and engaging with the aesthetic. Like The Latina Feminist Group (2001), "we seek those spaces within and across borders where women share parallel emotional and psychic terrain along with intersecting political agendas as a means of theorizing about our experiences." (p. 5).

In the forthcoming, we provide a bird's eye view of our organic conversations during our retreat about: how women of color feminisms inspire us; imagining/defining space; tensions within our sisterhoods; transforming (inner)coloniality by embracing our lived herstories; and how Chicana and Black feminisms and Womanism transform educational studies. We leave readers with hopes for our-selves, our fields, our sisters, and for the world. While not exact tellings of our pláticas ${ }^{1}$ during our retreat, we have captured and share the essence of burning questions, ideas, and hopes that arose for us when thinking and talking about women of color feminisms and educational studies.

Interlude: We encourage readers to seek information about some of the phrases we use that are not explicitly explained. This is how we've had to engage in most written word, forced to know and learn about white male histories for the majority of our educational careers, often with little guidance or prior understanding of dominant knowledge positioned as universal. We implore our readers to do the same as an act of solidarity_experiencing what Others have had to do to survive.

\footnotetext{
${ }^{1}$ As cited in Saavedra \& Pérez (in press), Fierros and Delgado Bernal (2016) explain that "pláticas align with the strong feminist tradition of theorizing from the brown body, and therefore, the modes of interaction and analysis are collaborative and attentive to the many ways of knowing and learning in our communities" (p. 116).
} 


\section{How Women of Color Feminisms Inspire Us}

Black and Chicana feminisms and Womanism are different from white patriarchal theories dominant in critical educational studies. While they share the purpose of analyzing power, importantly, women of color feminisms are conceptualized from lived experiences - theory is not separated from flesh (Moraga \& Anzaldúa, 1983). As readers of Black and Chicana feminisms and Womanism (by "readers" we mean theory is read intellectually, spiritually, and corporeally), we engage with theory in very intimate ways, on a personal level - a sharp departure from how white men have theorized, and thus, what they've been able to inspire in women of color (Pérez, 2017).

Chicana feminists, for example, have embraced testimonios to legitimize marginalized lived experiences and serve as a source of individual and collective empowerment. In testimonios, the teller is in a position of authority as a knower, as the producer and holder of knowledge (Delgado, Bernal, Burciaga, \& Flores Carmona, 2012; Saavedra, 2011). Similarly, Black feminists seek to legitimize and elevate marginalized knowledges through aesthetic expression. Referencing Alice Walker's (1983) In Search of Our Mother's Gardens, hooks (1995) ${ }^{2}$ explains how Walker:

acknowledges the way poor black women expressed their concerns with beauty in the growing and arranging of flower gardens. Offering the example of her own mother, Walker declares: "Her face, as she prepared the Art that is her gift, is a legacy of respect she leaves to me, for all that illuminates and cherishes life. She has handed down respect of the possibilities — and the will to grasp them." (p. 120)

Through aesthetic expressions and the use of methodologies such as Chicana feminist testimonios, as educational scholars, we have found solace in our identities and herstories being intimately tied to and represented in women of color feminisms. Feeling such profound connections has been necessary for us to survive, thrive, and transform white, patriarchal, and heteronormative educational spaces. We can relate with Delgado Bernal (2008) when she says "combining my sense of being an "outsider" with my growing confidence, skills, and different forms of knowledge allowed me to redefine that marginal space as a site of empowerment (hooks, 1984)" (p. 141).

Marginal spaces as sites of empowerment are not only felt within our-selves as individuals, but extend beyond to the collective. During our retreat, we found that we all dance between the collective and individual to resist oppression. The aim is never for an individual to step on anOther to advance oneself, rather to embrace and foster a sisterhood. In addition to nurturing and being part of the collective within and among marginalized communities, women of color feminisms have inspired us to think about connectivity in ways that traverse identity divisions. Womanism, in particular, moves us beyond the borders of our identities, and suggests that we are

\footnotetext{
${ }^{2}$ In hooks 1995 text Art on my mind: Visual politics, there are no references, and therefore, no reference to page numbers from texts hooks cites. This particular quote, however, can be found in Walker's 1983 text on pp. 241-242.
} 
all connected (human and more than human) through energies within a vast universe (Maparyan, 2012). Maparyan (2012) suggests:

Commonweal... refers to "the state of collective well-being"; that is "the optimization of well-being for all members of a community (Maparyan, 2006, p. xxv)." Who is "the community"? From a womanist perspective, community is conceived as a field of overlapping circles of varying scales - from a family to a group of friends to all people who share a certain identity or affinity to all humanity, conceptually centered at the level of humanity as a whole. (p. 45)

Through these and other notions of collectiveness, women of color feminisms have inspired transformations in the world. Although some scholars (particularly those who have taken a posthumanist/postqualitative turn) have expressed in public forums that critical lenses (e.g., those inspired by women of color and Foucault alike), have done little to provoke social change, we contend that Black and Chicana feminisms and Womanism have indeed been actionable both historically and contemporarily. As an example, Springer (2005) sustains that "black feminists are, historically, the first activists in the United States to theorize and act upon the intersections of race, gender, and class" (p. 2) - a major contribution to the intersectionality (Crenshaw, 1991) of social justice. Women of color feminists have also incited transformation through spiritual activism. Maparyan (2012) suggests that "from the spiritual realm may be gained intuition, inspiration, and illumination, all of which are vehicles for the betterment of life on Earth" (p. 56). We have each seen and felt these larger transformations in addition to continually engaging in our own conocimiento. As Anzaldúa (1987) asserts, when we change ourselves, we change the world.

In the current political climate, it's essential that we draw inspiration, strength, and wisdom from our ancestors, elders, and sisters. Black and Chicana feminisms and Womanism continue to be relevant and transformative in our lives and the lives of marginalized peoples. To suggest otherwise is insulting, misguided, and uninformed. As Anzaldúa (2002) reminds us:

Empowerment comes from ideas - our revolution is fought with concepts, not with guns, and it is fueled by vision. By focusing on what we want to happen, we change the present. The healing images and narratives we imagine will eventually materialize. (p. 5)

Interlude: During our retreat, as we ascertained our intimate connections to, and the multiple meanings of women of color feminisms, we began to grapple with the notion of space.

\section{What is Space?}

When thinking about how space has been theorized, we turn to postcolonial traditions of third space (Bhabha, 1994), and then move towards women of color, feminist ideas (Pérez, 1999; Anzaldúa, 1987; Sandoval, 2000). Anzaldúa (1987) enacts a feminist concept of third space in Borderlands, recognizing it as a place created by intersectional identities. A Chicana feminist third 
space embodies inbetweenness, where contradictions co-exist in order to create a new consciousness, or a mestizaje. Chela Sandoval (2000) further identifies third-space as an alliance or feminist movement that counters white male hegemony. We have each experienced academic spaces within educational studies that have not always valued our feminista knowledges - even at times within groups made up of our own cultural heritages (The Latina Feminist Group, 2001) so we've found that crossing borders into a liminal third space is necessary. Thus, a woman of color/feminist third space can be a practice and/or a location. As a practice, when entering a new mestizaje it reveals a differential consciousness ${ }^{3}$, where one is capable of grappling with contradictions and engaging creatively with/in colonized spaces (Licona, 2005).

As a location, a women of color third space has the potential to foster shared understandings and meaning-making where lived experiences can be theorized (Bañuelos, 2002). Having these spaces para platicar has legitimized our-selves by allowing us to share and problematize the tensions we've experienced. This marginal space then becomes a site of empowerment, felt not only within our-selves as individuals, but extended beyond to the collective. The five of us understand the importance of making time to create such a space. Once with each other at our retreat, we understood and felt the necessity of being present where we could simultaneously experience solitude (to be away from the white, patriarchal, and heteronormative spaces of higher education), though at the same time, experience comradery in the presence of a sisterhood - a collective third space. hooks (2002) cites Marilyn Fry's ${ }^{4}$ (1992) work, in which she states:

to make a difference...women have to do impossible things, think impossible thoughts, and that is only done in community. Without a community of sense, an individual cannot keep hold of her radical insights, she becomes confused, she forgets what she knew...We call each other to creative acts of courage, imagination, and memory, but they are literally impossible without a community of women which recognizes and authorizes women's initiatives. (p. 137)

Black and Chicana feminisms and Womanism incite a connection to each Other, a coming together and sharing of knowledges. These spaces give us the opportunity to learn and grow from one another, and most especially, to learn to honor who we are and where we are.

Interlude: In our negotiations of space, we acknowledged the messiness that can occur and be felt within our own sisterhoods. We share the tensions that we've explored and problematized during our retreat.

\footnotetext{
${ }^{3}$ Differential consciousness is a term deployed in Chela Sandoval's Methodology of the Oppressed (2000) (as cited by Licona, 2005) and refers to a consciousness that "arises between and through [different] meaning systems" (p. 180). Its subject is able to function within and beyond dominant ideologies. It captures the movement that joins different networks of consciousness for purposes of coalition and ultimately transformation.

${ }^{4}$ In hooks 2002 text, Communion: The female search for love, there is not a reference provided for Marilyn Fry's 1992 book. Therefore, we cannot provide a page number citation for Fry's work.
} 


\section{Tensions Within Our Sisterhoods}

Women of color perspectives allow for the interconnection of our inherited Cartesian schisms in body, mind, and soul, to embrace our-selves as integrated beings and to be active participants in the creation of our herstories. In a hierarchical world shaped by neoliberalism, power, and greed, challenging colonialism requires courage, empowerment, and collective action. As we hone these agentic abilities, we look to Chicana and Black feminism and Womanism for paths that take us beyond the borders of our identities as Black, Latina, Chicana, and mixed race peoples, into the (other)humanness and spiritual/embodied connections of our-selves. Womanism, like Chicana and Black feminism, calls for a revolution of spirit and soul which leads to action and world-wide transformations, an activism that sees women and other allies as the stewards of each other, the Earth, and all of creation (Maparyan, 2012).

From the colonial silencing of lived herstories, however, we must acknowledge that tensions have existed within our own sisterhoods. The distractions caused by internalized oppressions used to separate us, by appearing to afford some groups more access to the wealth and benefits of society over others, pits us against each other and creates paths of quicksand to traverse as we attempt to cultivate sisterhoods. An example is how education and educational advancement have become passports to "opportunity" in the United States - a ticket to the neoliberal dream (Carr \& Porfilio, 2010). Yet, opportunities afforded by education are inequitable or withheld entirely from marginalized youth through limiting access, blaming the Other for circumstances created by systemic oppression, and policies that confine education to standards that fail to reflect the lives of minoritized children (Delpit, 2012; Souto-Manning, 2013). This has created a flurry of competition for resources, hegemony among Others, and even the denial of one's culture in order to "fit" and "achieve" within the parameters of white, colonialist educational standards (Saavedra \& Pérez, 2012).

In our pláticas during our retreat we have acknowledged how, as women of color, we can at times embody this inherited Othering, creating tensions in our sisterhoods - even as we attempt to bridge the divide across a place of pain and healing. We've each experienced the questioning, for instance, of who might be suffering more or who is the most disenfranchised among us. These become echoes in our hearts that keep us from hearing/knowing/feeling one another amid our own, allconsuming pain; a pain that can make the colonized the colonizer (Collins, 2008) at the expense of subconsciously benefitting from anOther's more immediate, or more foregrounded, oppression. As we sat and pondered how we may find strength and inspiration to surge ahead in our pursuit for mutual support, our breath was momentarily halted by the realization of a tier-ing of oppression to which we may fall prey without even noticing. Being women of color, we are conscious of inhabiting the spaces created by our colonial histories and the internalized habits we might keep repeating. 
Black and Chicana feminist and Womanist lenses have taught us that although many barriers have been erected (even within our sisterhoods), together we have the power to breakdown tensions through mutual caring, love, and commonweal ${ }^{5}$. Women of color perspectives are more than just theories, more than intellectual or cultural movements. They are places of safety and healing where we can build connections to forge across our herstories of oppression, alienation, and disenfranchisement, a way to embody our (other)humanness and go beyond the borders of our individual identities (Anzaldúa \& Keating, 2002). Anzaldúa (2009) reminds us that we are always in the process of healing. She contends:

Coyolxauhqui is my symbol for the necessary process of dismemberment and fragmentation, of seeing that self or the situations you're embroiled in differently. It is also my symbol for reconstruction and reframing, one that allows for putting the pieces together in a new way. The Coyolxauhqui imperative is an ongoing process of making and unmaking. There is never a resolution, just the process of healing. (p. 312)

As we embrace Coyolxauhqui and collectively channel the wisdoms of our ancestors, we hope to continue to support each other and to heal our fractured wounds, both within and beyond our sisterhoods.

Interlude: As we continued to express our points of connection during our retreat, we found that we've had similar experiences negotiating coloniality within our own family herstories.

\section{Embracing our lived herstories: Transforming (Inner)Coloniality by Drawing Upon and Sharing Women of Color Wisdoms}

Micro-aggressions can occur even within our own Brown and Black spaces (Collins, 2005) and can be hidden as social expectations that categorize women as inferior (Torres \& Pace, 2005). Gender social hierarchies in which privilege and power are enacted "have always been fundamental in upholding White/European patriarchal hegemony in the context of colonialism" (Bernard, 2016, p. 2). For Latinas, when colonialism repeats over generations, it maintains the legacy that spaniards left after la conquista in Latin American countries (Harding, 2002). Thus, many of us have lived the imposition of patriarchal coloniality in our childhood home spaces, experiencing with our mothers a complex contradiction of both oppression and empowerment (Collins, 2008). Villenas and Moreno (2001) explain:

As daughters of our mothers, we indeed struggle with the tensions and contradictions of our mothers' gloom in relation to how we ourselves are to be in this world as mujeres (women) with hopes, dreams, and creative energy. Yet, we most often learn to question

\footnotetext{
${ }^{5}$ Maparyan defines commonweal as "the state of collective well-being" and the "optimization of well-being for all members of the community” (2012, p. 45).
} 
patriarchy rather than deny our mothers (Andrade and González Le Denmat, 1999). (p. 672)

From these lived herstories, we've discussed how our colonial legacies can manifest by taking on, for instance, impostor syndrome in our work as educational scholars. As we've become cognizant of how unproductive and damaging this self-criticism can be, we have redirected our thoughts towards the wisdom we've learned and embody from our ancestors and familias, what Lorde (1992) posits as "enduring qualities of the human spirit" (p. xv), reminding us that within our own colonial contradictions lies resistance and empowerment. Although patriarchy may have been reified by some women in our families, these mujeres have also imparted a sense of strength, community, and survival (Villenas \& Moreno, 2001). Anzaldúa (2009) reminds us:

Besides dealing with my own personal shadow, I must contend with the collective shadow in the psyches of my culture and nation - we always inherit the past problems of family, community, and nation. I stare up at the moon, Coyolxauhqui, and its light in the darkness. I seek a healing image, one that re-connects me to others. I seek the positive shadow that I've also inherited. (p. 304)

At our retreat, we discussed how we might confront our shadow beasts by collectively channeling women of color wisdoms and ancestral knowledges.

Moreover, we have felt compelled to share our grapplings and wanderings among each Other and with a wider audience in order to break long held silences. Lorde (1989) urges that "silence has never brought us anything of worth" (p. 8). She continues "without a community there is certainly no liberation, no future, only the most vulnerable and temporary armistice between me and my oppression" (Lorde, 1980, p. 11). Lorde illuminates for us that if we wish to shed matrices of domination (Collins, 2008) taken on by our colonial histories, we must work collectively to share our wisdoms with our selves, families, colegas, students, and even those who may position themselves as our adversaries (Anzaldúa \& Keating, 2002; Maparyan, 2012). These wisdoms have always been in us and the women in our lives. Chicana and Black feminisms and Womanism have allowed us to retrieve these deep and long held (corporeal) knowledges so we can continue to challenge coloniality in ourselves, among our communities and the world, and in educational studies.

Interlude: As women of color feminisms have shifted our ways of being, these theories have simultaneously changed our pedagogical lenses and have provoked us to question and challenge norms within higher education, technology, and early childhood studies (our respective fields), which have been dominated by white, heteronormative, patriarchal, and colonialist positionings. 


\section{Transforming Educational Studies with Women of Color Feminisms}

As we've discussed at length throughout our colloquium, women of color onto-epistemologies center lived experiences and knowledges of the marginalized (Collins, 2000), and therefore, inherently challenge post-positivist, standardized notions of education. These challenges transform the way we, as pedagogues, view knowledge and how we approach our work. During our retreat, we shared how women of color feminisms have shaped our own experiences in educational studies and exchanged strategies to help us continue to transform our praxis. These include centering lived knowledges of our elders and communities in the curriculum and incorporating advances in technology such as social media to contextualize and bring important issues into the classroom space. An example is sharing videos, podcasts, and engaging in real time conversations during class to connect with Others involved in (and documenting) resistance happening "on the ground." Making connections through forums like Skype or FaceTime not only serves as a pedagogical tool which is dialogic and reciprocal (information and knowledge doesn't flow in one direction), but also allows us as women of color (and our students from marginalized positionalities) to potentially feel a bond and sense of community beyond our classroom doors. This connection conveys the importance of knowledge needing "to be functional in helping address actual problems" (Collins, 2013, p. 26), and in turn, changes how we approach educational studies - from viewing curriculum to supposedly neutral (which we know is never possible), to making our course content overtly political and action oriented.

As we've affirmed the lived experiences of Others in our classes, we've also affirmed the knowledges of our students. hooks (1994) explains “...the professor must genuinely value everyone's presence. There must be an ongoing recognition that everyone influences the classroom dynamic, that everyone contributes... Used constructively, they enhance the capacity of any class to create an open learning community" (p. 8). Educators, then, must shift from being sages on the stage to being learners and active participants in classroom spaces (hooks, 1994). Since we seek to find balance between our-selves and the collective (Collins, 2008), we've found it imperative to foster these negotiations in our classes, asking students to define their own intersectional identities while finding connections with peers (hooks, 2000a). We agree with Keating (2002) when she shares:

My experiences have taught me that the recognition of our radical interconnectedness offers a vital key to long-term individual/collective change, a crucial point of departure in our work for social justice: if we're all radically interconnected, then the events and belief systems impacting my sisters and brothers in South America or Central Park or Jerusalem have a concrete effect on me. Spiritual activism insists that we all rise and sink together. (p. 19) 
Thus, unlike educational spaces that value competition amongst students, women of color ontoepistemologies foster connections and relationship building (hooks, 1994), inspiring spiritual activism that attempts to move us towards collective knowing. As Beauboeuf-Lafontant (2002) posits:

womanist teaching offers ways to repair such relational breakdowns by emphasizing the following: the agency that each of us has to treat others as our own; the obligation we have to understand as fully as we can the world around us; and the responsibility we have to make sure that our actions contribute to the larger human goal of freedom for all. (p.84)

Chicana and Black feminisms and Womanism also inspire pedagogies that include student engagement with the aesthetic, such as through photovoice or working with clay, in order to (re)present lived experiences and political action through myriad expressions (Pérez, Ruiz Guerrero, \& Mora, 2014; Ruiz Guerrero \& Pérez, in press). Along with rethinking how students express knowledge, women of color pedagogies change the way learning is evaluated. In our work, we seek to view learning as it connects to the experiences of students, which is not measurable through testing or rote memorization. Rather, we attempt to cultivate a more organic "measure" of student engagement through activities that encourage dialogue, gaining knowledge of and being active participants in the surrounding borderland communities, and grappling with tensions that can arise when confronting our own biases. As hooks (1994) reminds us, "students are often silenced by means of their acceptance of [dominant] class[room] values that teach them to maintain order at all costs" (p. 178). We, too, as educators can fall prey to rigid approaches to "teaching and learning," and therefore, must be continually reflexive about our praxis.

Black and Chicana feminisms and Womanism have helped us to acknowledge that education is not neutral and to provoke transformation in educational spaces. This means looking beyond what we believe to have become apolitical terms, such as "diversity" and "inclusion," to more radical notions of praxis, ones that are tangible and relatable for our students and also actionable. As hooks (1994) states, "I celebrate teaching that enables transgressions - a movement against and beyond boundaries" (p. 13). For us, this begins by embedding women of color feminisms in every aspect of educational studies.

Interlude: As we sat around the kitchen table and in the living room, prepared and ate meals, drank wine and listened to music, took walks, and played pool, we discussed what we hope for as we return to our home/profe lives.

\section{What We Hope For}

Although many of our sisters, brothers, and elders' knowledges have indeed begun to be written into history, we feel that there is still much work to be done. In the foundations of educational studies, we find it astounding that there is a continued lack of marginalized peoples' wisdoms. 
Thus, we agree with Moraga \& Anzaldúa (2015) when they say, "I write to record what others erase when I speak, to rewrite the stories others have miswritten about me, about you" (p. 167). We no longer wish to be represented in marginal ways, only having our knowledges and lives accessed by those who seek it out in journals, books, and other materials - rather, we strongly contest that these wisdoms (and actual women of color) become part of the fabric of our fields. It's not enough to only include us, our children, and communities in educational discourses that assume we need to be fixed, as having deficits that must be rectified in order to close a supposed achievement gap (Pérez \& Saavedra, 2017). The symbolism of our invisibility (or visibility only when positioned as deficit) can feel defeating - yet we are empowered by our Black and Chicana feminist and Womanist standpoints.

Coming together as a sisterhood to share these and Other wisdoms, we have felt great hope and strength to continue in the struggle, la lucha. In educational studies, we imagine a place to influence teachers who come from and/or work in our communities. We have the opportunity to challenge the status quo (hooks, 1994), and constantly ask questions of our-selves and Others so that we are released from our hegemonic haze. We must continue to open doors and create spaces for self-awareness and to encourage marginalized peoples to share what's within so that we can find commonalities among us and become part of a better and more just world. This call to action takes perseverance, spiritual healing within and among our-selves and with the Earth, and self/collective-love. This is what we have felt, learned, and are inspired to employ as we continue to forge sisterhoods and theorize with women of color feminisms in educational studies and beyond.

Interlude: We leave our retreat with a sense of belonging and a renewed strength, hope, and desire for action. There exists a calling from within and from our ancestors which guides us on our spiritual, collective, and transformative journeys to continue to write women of color into educational studies and the herstories of the world. 


\section{References}

Andrade, R., \& González Le Denmat, H. (1999). The formation of a code of ethics for Latina/Chicana scholars: The experience of melding personal lessons into professional ethics. Frontiers: A Journal of Women Studies, 20, 151-160.

Anzaldúa, G. E. (1987). Borderlands/la frontera. San Francisco: Aunt Lute Books.

Anzaldúa, G. E. (2002). (Un)natural bridges, (un)safe spaces. In G. E. Anzaldúa \& A. Keating (Eds.), This bridge we call home: Radical visions for transformation (pp. 1-5). New York: Routledge.

Anzaldúa, G. E. (2009). Let us be the healing of the wound: The Coyolxauhqui imperative-la sombra y el sueño. In A. Keating (Ed.), The Gloria Anzaldúa reader (pp. 303-317). Durham, NC: Duke Univeristy Press.

Anzaldúa, G. E. \& Keating, A. (2002) (Eds.), This bridge we call home: Radical visions for transformation. New York, NY: Routledge.

Bañuelos, L.E. (2006). "Here they go again with the race stuff": Chicana negotiations of the graduate experience. In D. Delgado Bernal, C. A. Elenes, F. E. Godinez, \& S. Villenas (Eds.), Chicana/Latina education in everyday life: Feminist perspectives on pedagogy and epistemology (pp. 95-112). Albany, NY: State University of New York Press.

Beauboeuf-Lafontant, T. (2002). A womanist experience of caring: Understanding the pedagogy of exemplary black women teachers. Urban Review, 34(1), 71-86.

Bernard, A. A. F. (2016). Colonizing Black female bodies within patriarchal capitalism: Feminist and human rights perspectives. Sexualization, Media, \& Society, 1, 1-11.

Bhabha, H.K. (1994). The location of culture. London: Routledge.

Carr, P.R., \& Porfilio, B.J. (2010). The phenomenon of Obama and the Agenda for Education: Can hope audaciously trump neoliberalism? Charlotte, NC: Information Age Publishing.

Collins, P. H. (2005). Black sexual politics: African Americans, gender, and the new racism. New York, NY: Routledge.

Collins, P. H. (2008). Black feminist thought: Knowledge, consciousness, and the politics of Empowerment (3rd edition). New York: Routledge.

Collins, P.H. (2013). On intellectual activism. Philadelphia, PA: Temple University Press.

Crenshaw, K. W. (1991). Mapping the margins: Intersectionality, identity politics, and violence against women of color. Stanford Law Review, 43(6): 1241-99.

Delgado Bernal, D. (2008). La trenza de identidades: Weaving together my personal, professional, and communal identities. In K. P. González, \& R. V. Padilla, Doing the public good: Latina/o scholars engage civic participation (pp. 134-148). Sterling, VA: Stylus Publishing.

Delgado, Bernal, D., Burciaga, R., \& Flores Carmona, J. (Eds). (2012). Chicana/Latina testimonios: Mapping the methodological, pedagogical and political. Equity \& Excellence in Education, 45(3), 363-372.

Delpit, L. (2012). “Multiplication is for white people:" Raising expectations for other people's 
children. New York: New Press.

Fry, M. (1992). Willful virgin: Essays in feminism, 1976-1992. Berkeley, CA: Crossing Press. Harding, M. (2002). Altering masculinities: The Spanish conquest and the evolution of the Latin American machismo. International Journal of Sexuality and Gender Studies, 7(1), 1-22. hooks, b. (1984). Feminist theory: From margin to center ( $1^{\text {st }}$ Edition). Cambridge, MA: South End Press.

hooks, b. (1994). Teaching critical thinking: Practical wisdom. New York, NY: Taylor \& Francis.

hooks, b. (1995). Art on my mind: Visual politics. New York, NY: The New Press. hooks, b. (2000a). Feminism is for everybody. Chicago, IL: Pluto Press.

hooks, b. (2000b). Feminist theory: From margin to center (2nd Edition). Cambridge MA: South End Press.

hooks, b. (2002). Communion: The female search for love. New York, NY: William Morrow/HarperCollins.

Keating, A. (2002). Charting pathways, marking thresholds...a warning, an introduction. In G. E. Anzaldúa \& A. Keating (Eds.), This bridge we call home: Radical visions for transformation (pp. 6-20). New York: Routledge.

Licona, A. C. (2005). (B)orderlands' rhetorics and representations: The transformative potential of feminist third-space scholarship and zines. NWSA Journal, 17(2), 104-129.

Lorde, A. (1980). The cancer journals. San Francisco, CA: Aunt Lute Books.

Lorde, A. (1984). Sister Outsider: Essays and speeches. Freedom, CA: The Crossing Press Feminist Series.

Lorde, A. (1992). Undersong: Chosen poems old and new; Revised edition. New York, NY: W. W. Norton \& Company, Inc.

Maparyan, L. (2006). Womanism: On its own. In L. Phillips (Ed.), The womanist reader (p. xixlv). New York, NY: Routledge.

Maparyan, L. (2012). The womanist idea. New York: Routledge.

Moraga, C., \& Anzaldúa, G. (1983). This bridge called my back: Writings by radical women of color. Watertown, MA: Persephone Press.

Moraga, C., \& Anzaldúa, G. (Eds.). (2015). This bridge called my back: Writings by radical women of color. Suny Press.

Pérez, E. (1999). The decolonial imaginary: Writing Chicanas into history. Bloomington, IN: Indiana University Press.

Pérez, M.S. (2017). Black feminist thought in early childhood studies: (Re)centering marginalized feminist perspectives. In K. Smith, K. Alexander, \& S. Campbell (Eds.), Feminism(s) in early childhood: Using feminist theories in research and practice (pp. 4962). New York, NY: Springer.

Pérez, M.S., Ruiz Guerrero, M.G., \& Mora, E. (2016). Black feminist photovoice: Fostering critical awareness of diverse families and communities in early childhood teacher education. Journal of Early Childhood Teacher Education, 37(1), 41-60. 
Ruiz Guerrero, M.G., \& Pérez, M.S. (In press). Rethinking health, safety, and nutrition through a Black feminist lens: An early childhood teacher educator's transformative journey. In N. Yelland \& D. Frantz Bentley (Eds.). Found in translation: Connecting reconceptualist thinking with early childhood education practices. New York, NY: Routledge.

Saavedra, C. M (2011). Language and literacies in the borderlands: Acting upon the world through testimonios. Language Arts, 88(4), 261-269.

Saavedra, C.M., \& Pérez, M.S. (In press). Global south approaches to bilingual and early childhood teacher education: Disrupting global north neoliberalism. Policy Futures in Education.

Saavedra, C. M. \& Perez, M. S. (2012). Chicana and Black feminisms: Testimonios of theory, identity and multiculturalism. Equity and Excellence in Education, 45(3), 1-14.

Sandoval, C. (2000). Methodology of the oppressed. Minneapolis, MN: University of Minnesota Press.

Souto-Manning, M. (2013). Multicultural teaching in the early childhood classroom: Approaches, strategies, and tools preschool-2 ${ }^{\text {nd }}$ grade. NY: Teachers College Press.

Springer, K. (2005). Living for the revolution: Black feminist organizations 1968-1980. Durham, NC: Duke University Press.

The Latina Feminist Group. (2001). Telling to live: Latina feminist testimonio. Durham, NC: Duke University Press.

Torres, G., \& Pace, K. (2005). Understanding patriarchy as an expression of whiteness: Insights from the Chicana movement. Washington University Journal of Law \& Policy, 18(1), 128-172.

Villenas, S., \& Moreno, M. (2001). To valerse por si misma between race, capitalism, and patriarchy: Latina mother-daughter pedagogies in North Carolina. International Journal of Qualitative Studies in Education, 14(5), 671-687.

Walker, A. (1983). In search of our mother's gardens. NY: Harcourt Brace Jovanovich. 